МУЗИКА. ЕСТЕТИКА

УДК 785:7.071.1(477)

DOI: 10.37026/2520-6427-2021-106-2-148-152

\author{
Ірина ГРИНЧУК, \\ кандидат педагогічних наук, \\ доиент кафедри музикознавства \\ та методики музичного мистецтва \\ Тернопільського національного \\ педагогічного університету \\ імені Володимира Гнатюка \\ м. Тернопіль, Україна \\ ORCID: 0000-0001-5383-8665 \\ e-mail:iryna.hk77@gmail.com
}
Анатолій БАНЬКОВСЬКИЙ, доцент кафедри музикознавства та методики музичного мистеитва Тернопільського національного педагогічного університету імені Володимира Гнатюка, заслужений прачівник культури Украӥни, м. Тернопіль, Украӥна
ORCID: 0000-0003-2668-4423
e-mail:1958anaban@gmail.com

\title{
ІНСТРУМЕНТАЛЬНА МУЗИКА УКРАЇНСЬКИХ КОМПОЗИТОРІВ: СТИЛЬОВИЙ ТА РЕПЕРТУАРНИЙ АСПЕКТИ
}

Анотація. У статті висвітлено основні теоретичні підходи до категорій «національний музичний стиль» та «феномен украӥнської музичної мови» (за О. Козаренком). Окреслено проблеми репертуарного забезпечення виконавських інструментальних індивідуальних та ансамблевих класів, інформативного музикознавчого і методичного супроводу навчфально-методичних посібників. Особливу увагу зосереджено на фортепіанному репертуарі украӥнських композиторів, окреслено стильовий, жанровий та інтерпретаційний зрізи у проблематииі підручникотворення. Представлено змістовне наповнення серії авторських навчально-методччних посібників фортепіанними творами украӥнських композиторів, укомплектованими за стильовим і жанровим підходами, монографічним принцииом (І. Гринчук). Хронологічні рамки представленого репертуару включають твори композиторів різних регіонів України - від долисенківського періоду до сучасності. Репрезентовано посібники, адресовані інструментальним колективам (А. Баньковський, Д. Губ'як), зокрема авторські обробки та аранжування, відповідно до специфіки ансамблевого складу. Зроблено висновки щзодо актуальності та перспективності означеного виду навчально-методичної продукиії з метою забезпечення якісної підготовки майбутніх учителів музичного мистецтва, організаторів просвітницької та соціокультурної діяльності.

Ключові слова: інструментальна музика, украӥнські композитори, виконавський та педагогічний репертуар, навчальні посібники.

\author{
Iryna HRYNCHUK, \\ PhD (Pedagogy), \\ Associate Professor of the Department of Musicology \\ and Methods of Music Art, \\ Volodymyr Hnatyuk Ternopil National \\ Pedagogical University, \\ Ternopil, Ukraine, \\ ORCID: 0000-0001-5383-8665 \\ e-mail:iryna.hk77@gmail.com \\ Anatoliy BANKOVSKY, \\ Associate Professor of the Department of Musicology \\ and Methods of Music Art, \\ Volodymyr Hnatyuk Ternopil National \\ Pedagogical University, \\ Honored Worker of Culture of Ukraine, \\ Ternopil, Ukraine, \\ ORCID: 0000-0003-2668-4423 \\ e-mail:1958anaban@gmail.com
}




\section{INSTRUMENTAL MUSIC OF UKRAINIAN COMPOSERS: STYLE AND REPERTUARY ASPECTS}

\begin{abstract}
The problem of theoretical and performing analysis and interpretation of works by Ukrainian composers determines such an aspect as the representation of works in the relevant repertoire collections, which have a certain educational and methodological support.

The purpose of the article is to present the author's approaches to the compilation of educational and methodical literature from the works of Ukrainian composers on the example of piano literature and instrumental arrangements.
\end{abstract}

The main theoretical approaches to the category «national musical style», "phenomenon of the Ukrainian musical language» (according to O. Kozarenko) are highlighted. The problem of repertoire of professional performing instrumental individual and ensemble classes, informative musicological and methodical support of teaching aids is posed.

Attention is focused on the piano repertoire of works by Ukrainian composers in stylistic, genre, interpretive terms as a problem of textbook creation. The content of a series of author's educational and methodical manuals from the works of Ukrainian composers, completed according to stylistic and genre approaches, according to the monographic principle (I. Hrynchuk).

The chronological framework of the presented repertoire covers the works of composers - predecessors of $M$. Lysenko, - to contemporary artists, representing different regions of Ukraine.

There are manuals addressed to instrumental groups (A. Bankovsky, D. Gubyak), which include author's arrangements and arrangements, in accordance with the specifics of the ensemble.

Conclusions are made about the relevance and prospects of this type of educational and methodological products to ensure the process of training future music teachers, organizers of educational and socio-cultural activities.

Key words: instrumental music, Ukrainian composers, performing and pedagogical repertoire, textbooks.

Постановка проблеми. Процес фахової підготовки майбутнього вчителя музичного мистецтва у закладі вищої освіти ставить високі вимоги до рівня сформованості його фахових компетентностей, зокрема виконавського. Зважаючи на це, постає проблема відповідного методичного забезпечення викладання у виконавських класах.

Як свідчить аналіз виконавської практики, актуалізується завдання опанування кращими зразками інструментальної музики українських композиторів як значного за своїм змістом пласту національної культури, пов'язаного із загальними тенденціями розвитку європейського та світового музичного мистецтва.

Аналіз наукових досліджень та публікацій. Інструментальна музика українських композиторів - цілісний предмет наукових досліджень різних напрямів, зокрема історико-культурологічного, музикознавчо-теоретичного, виконавсько-інтерпретаційного та дидактично-методичного. Так, творчість українських композиторів як втілення феномена національного стилю в музиці представлено у розвідках Н. Герасимової-Персидської, Ю. Ясиновського, О. Цалай-Якименко, О. Козаренка, Л. Корній і Б. Сюти, О. Бенч та ін. Композиторська творчість українських митців як творців фортепіанного репертуару є предметом досліджень М. Дремлюги, В. Клина, Н. Кашкадамової, О. Козаренка, О. Лігус, О. Олійник, Н. Ревенко, Л. Свірідовської, О. Фрайт, М. Ілечко та ін.

Серед сучасних досліджень фортепіанного мистецтва варто виокремити наукові праці Д. Андросової «Від модерного до постмодерного дискурсу фортепіанного мистецтва XX - початку XXI ст.: виконавська специфіка» та Н. Рябухи «Трансформація звукового образу світу у фортепіанній культурі: онто-сонологічний підхід», в яких окреслено проблеми аналізу творів українських композиторів.

Опанування різностильових творів, передусім тих, в яких яскраво виражені характеристики національного стилю, є однією з основних проблем у працях із мистецької педагогіки та освіти (О. Рудницька, О. Олексюк та ін.); теорії і практики підготовки вчителя музичного мистецтва; музично-естетичного виховання, творчого розвитку школярів, організації різновидів діяльності та творчої активності на уроках мистецтва в умовах упровадження Концепції Нової української школи, зокрема й на етапі слухання та аналізу-інтерпретації музики (Л. Масол, І. Гринчук).

Проблема інтерпретації творів українських композиторів, теоретичного й виконавського аналізу обумовлює такий аспект - репрезентація творів у відповідних репертуарних збірках, які виконують роль своєрідного навчально-методичного забезпечення.

Мета статті - виокремити й схарактеризувати авторські підходи до розроблення навчально-методичної літератури, в змісті якої здійснено наукову інтерпретацію та екстраполяцію творів українських композиторів на прикладі фортепіанного репертуару та інструментальних аранжувань.

Виклад основного матеріалу дослідження. Iнструментальна музика українських композиторів, за твердженням I. Ляшенка, О. Козаренка, Л. Кияновської, - це значний за своїм змістом пласт національної культури, що демонструє доцентрові процеси як «кристалізацію» ознак національного музичного стилю, феномена української музичної мови (Козаренко, 2000); відцентрові процеси як міжнаціональні мистецькі взаємовпливи в контексті загальнокультурних динамічних процесів становлення епохальних та історичних музичних стилів, зокрема розвитку та модифікації різних жанрів інструментальної музики у їх загальноєвропейському та національному «зрізі» тощо (Михайлов, 1990).

Звертаючись до репрезентації власне ознак національного музичного стилю в обраних нами зразках фортепіанної літератури, опираємося на тези О. Козаренка, який зосереджує увагу на феноменологічних проявах 
національної музичної мови «...в артифікаційній творчості - ¥ї авторизованих моделях-варіантах», виокремлюючи етапи «... передстилю (давньоукраїнської музичної мови) та особливо стилю (музичної мови М. Лисенка та його наступників)» (Козаренко, 2000, c. 11).

Описуючи «репертуарну політику» у восьми виокремлених випусках навчально-методичних посібників, присвячених фортепіанним творам українських композиторів як репрезентантів різних мистецьких епох, напрямів і стилів, нами було здійснено аналіз досвіду дослідників-укладачів репертуарних хрестоматій, серед яких М. Степаненко, У. Молчко, О. Німилович, О. Рапіта, Л. Філоненко, Т. Завадська і О. Козачук (Завадська, Козачук, 2010) та ін.

У підготовлених нами посібниках, укладених за жанрово-стильовим підходом, хронологічні рамки включених до їх змісту творів охоплюють періоди від творів О. Лизогуба (1790-1839), М. Завадського (18281887), В. Заремби (1833-1902) (Корній, Сюта, 2014; Муха, 2004) та інших представників долисенківського періоду до творів наших сучасників - I. Небесного, А. Кармазіна, А. Школьнікової, І. Павлик (Гринчук, Горбач, 2019).

На прикладі відповідного нотного й інформаційно-методичного матеріалу зроблено спробу простежити основні тенденції укладання національного фортепіанного репертуару відповідно до становлення українського фортепіанного мистецтва в загальноєвропейському контексті.

Серед основних чинників означеного «інтеграційного» процесу на прикладі митців Західної України передусім варто виокремити такі моменти: навчання у провідних зарубіжних композиторів та педагогів європейських столиць; багатогранна концертно-гастрольна діяльність українських виконавців як в Україні, так і за iii межами, що стало підгрунтям для закладення традицій виконавських шкіл України (Кашкадамова, 2017).

Важливим чинником у зв'язку з цим є також безпосередня творча діяльність представників плеяди українських виконавців, композиторів та педагогів, які у зв'язку з певними суспільно-історичними обставинами змушені були емігрувати та долучалися до творення українського фортепіанного мистецтва поза українським культурним контекстом, «вписуючи» його таким чином у загальноєвропейський і світовий контекст. Відповідно на рівні композиторської творчості відбувалися процеси органічного сприйняття й переосмислення традиційних і новітніх стильових тенденцій європейського фортепіанного мистецтва, зокрема творення виконавського і педагогічного репертуару.

Окреслені вище позиції були закладені нами в основу відбору та репрезентації фортепіанних зразків. Для ілюстрації представимо рубрикацію навчально-методичних посібників. Якщо перші випуски включали лише дві рубрики - фортепіанні мініатюри та фортепіанні цикли, то в наступних випусках були вже представлені рубрики, репрезентовані зразками поліфонічної музики, варіаційного та сонатного жанрів.

Так, цікавим є співставлення Сонати B-dur Д. Бортнянського (близької за образною сферою та фактурним викладом до ранньої клавірної музики В.-А. Моцарта) як прикладу ранньокласичного стилю та першої частини Сонати a-moll M. Колесси (1939), в якій під авторською назвою «Слідами Довбуша» форма сонатного allegro наповнюється мелосом із яскраво вираженими фольклорними ознаками (так званий «гуцульський» лад, ритмо-формули коломийки, «гуцулки» та аркана, наслідування звучання народного інструментарію та традицій музикування з обігруванням-«колінцями» та ін.).

У шостому випуску, крім традиційних рубрик (фортепіанні мініатюри і фортепіанні цикли), представлено рубрики зі зразками жанрів етюду та прелюдії. Таким чином, ми намагалися прослідкувати становлення різних жанрів фортепіанної літератури в іiї історичній ретроспективі. Наприклад, у восьмому випуску, на нашу думку, доцільним і пізнавальним $є$ компаративний аналіз зразків одного жанру, зокрема прелюдій, на прикладі мініатюр братів Федора та Якова Якименків (Я. Степового).

Особливістю навчально-методичних посібників $€$ наявний у них інформативний та методичний матеріал, оскільки кожен випуск містить: короткі відомості про авторів репрезентованих творів; джерельні посилання; публікації методичного характеру, як-от рекомендації щодо виконання включених творів 3 елементами цілісного, виконавського та художньо-педагогічного аналізу, історії становлення репрезентованого жанру в українській фортепіанній літературі; матеріали, адресовані педагогам-піаністам.

Оскільки посібники активно використовуються у процесі фахової підготовки майбутнього вчителя музичного мистецтва, у випусках представлені матеріали, присвячені сучасним теоретичним і методичним засадам мистецької освіти (Л. Масол, 2006), які можна використати у процесі викладання навчальної дисципліни «Мистецтво» в закладах загальної середньої освіти. У додатках до посібників представлено авторські методики організації слухання музики школярами, серед яких - методика аналізу-інтерпретації музики (Гринчук, Бурська, 2008), втілена в серії «Щоденників музичних вражень», та посібнику-зошиті «Про що і як розповідає музика» (Гринчук, 2013).

Включені до збірників нотні матеріали використовувалися нами в експериментальній роботі, присвяченій формуванню емоційного інтелекту майбутнього вчителя мистецьких дисциплін із використанням методу створення узагальнених «емоційних партитур». Найбільш доцільним, на нашу думку, стало використання варіаційних циклів (варіації «Українка» Й. Витвицького), програмних циклічних форм, пов'язаних iз народним мелосом, танцювальними жанрами, суміжними видами мистецтва («Три ескізи» М. Лисенка, «Буковинська сюїта» А. Кос-Анатольського, «Три коломийки» М. Колесси, «Акварелі» Ф. Надененка, «Волинські акварелі» М. Вериківського, «Київський триптих» Б. Фільц, Партита № 5 М. Скорика та ін.).

Переконані, майбутніх педагогів зацікавлять: мініатюри $з$ авторською назвою, узагальненою програмою, закладеною в жанрі; емоційно-ціннісний, художньо-педагогічний аналіз фортепіанних п’єс В. Барвінського, Н. Нижанківського, С. Борткевича, М. Колесси, О. Білаша, М. Скорика, Б. Фільц, Ж. Колодуб, Я. Бобалік та ін. Крім того, цінним виконавським і дидактичним репертуаром 
є мініатюри сучасних українських композиторів (В. Квасневський, В. Філіпенко, Б. Севастьянов, Л. Жульєва, О. Бордюгова, О. Кимлик, Л. Шукайло, В. Гончаренко, С. Гримальський, І. Гайденко, Р. Лісова та ін.) із притаманною їм стилістикою, жанровою характерністю та яскравою емоційною образністю.

У нашому доробку є й монографічний випуск навчально-методичний посібник «Фортепіанні твори М. Вериківського», видання якого було приурочено 120-річчю від дня народження митця. До збірника увійшли твори, які вже були раніше видрукувані, тексти 3 архівних фондів ЦНБУ ім. В. Вернадського, а також раритетні нотодруки, серед яких - тексти 14 прелюдій, подарованих викладачеві М. Нівельт дочкою композитора, піаністкою і педагогом О. Вериківською (Гринчук, Горбач, 2016).

У збірнику також представлено статтю «Фортепіанні твори М. Вериківського: семантика і стилістика» й методичні рекомендації щодо їх виконання, рекомендовану літературу, зокрема й архівні фонди, та систематизовані матеріали ювілейних збірників всеукраїнських науково-практичних конференцій, наукових публікацій тощо.

Цінним матеріалом для нас стали спогади та методичні поради О. Вериківської (з якою авторка статті спілкувалася на Першій конференції Асоціації піаністів-педагогів України, що відбулася в Харкові у 1992 р.) передусім щодо виконання відомих «Волинських акварелей» (авторський рукопис циклу із написом «П'ять фортеп'янних мініатюр на білих клавішах» знаходиться в архівах Кременецького краєзнавчого музею).

Цикл задумувався як «15 маленьких п’єс у 49-ступеревому діатонічному До-мажорі». Це була ідея композитора, певною мірою обумовлена і його навчанням у Б. Яворського, що полягала у поєднанні 7-ми старогрецьких ладів. Як зазначають дослідники (В. Клин та ін.), iз цим твором в українську фортепіанну музику другої половини XX століття увійшов новий «звуковий образ» інтонуючого фортепіано (Клин, 1980). Цей цикл програмних мініатюр, найбільш залучений до навчально-педагогічної практики, засвідчив основні ознаки фортепіанного письма композитора, в якому поєдналися пізньоромантичні, імпресіоністичні, модерністські (конструктивні) начала, спостерігається тяжіння до узагальненої програмності із переважанням історико-етнографічної тематики, камерності вислову.

У додатках до посібника нами було вміщено: фото титульної сторінки, родинні та рідкісні світлини першої вчительки з фортепіано А. Сафонової (учениці Б. Яворського), фото з учнями, колегами-педагогами і науковцями, а також ті, що були зроблені до 5-річчя Музичного товариства ім. М. Леонтовича, афіші прем'єрних вистав та конференцій, титульні та окремі сторінки із нотодруків, публікації дочок Ірини та Олени Вериківських (Гринчук, 2016).

Крім згаданих вище «Волинських акварелей» i 14-ти маленьких прелюдій, до посібника увійшли Шість варіацій із балету «Весняна казка», «Гуцульський танець» та «Два танці», цикл «Веснянки» («Коло», «Зелений шум», «Ягілочка», «Молода»), мініатюри «Ягілочка», «Етюд», «Танець», «Войовничий марш» як зразки творчості міжвоєнного періоду, в яких віддзеркалилися полістилістичні тенденції фортепіанної творчості українських композиторів, зокрема поєднання пізньоромантичних, конструктивістських, фольклорно-етнографічних характеристик (Гринчук, Горбач, 2016).

Висвітлені нами раніше тематично-жанровий та монографічний підходи до укладання навчально-методичних посібників дають змогу досить цілісно представити картину становлення українського фортепіанного репертуару. Як засвідчили відгуки, навчально-методичні посібники стають актуальним матеріалом для виконавської і навчально-педагогічної практики у спеціалізованих мистецьких закладах, організації уроків музичного мистецтва у закладах загальної середньої освіти. Водночас уміщені в посібнику матеріали $є$ цінним надбання для дослідницьких проєктів (зокрема у нашому авторському курсі «Основи музичної інтерпретації»), написання курсових і магістерських робіт студентами мистецьких спеціальностей.

Пропонуємо ще один вид навчально-методичної продукції - навчальний посібник «Виконавський та навчальний репертуар у класі інструментального ансамблю (з репертуару ансамблю народної музики «Музи́ки»)» як результат упорядкування виконавського репертуару для певного виконавського складу, адресований студентам, викладачам мистецьких закладів, виконавцям-ансамблістам (Баньковський, 2018). До посібника увійшли аранжування та інструментування зразків народних українських пісень і танців, авторських творів українських митців другої половини XX - початку XXI ст., що були апробовані в роботі 3 ансамблем народної музики «Музи́ки».

До першого випуску посібника увійшли аранжування А. Баньковського для інструментального складу: «Фантазія на українські народні теми», «Весільна полька» (С. Орел), «Буковинський марш» (С. Орел), а також аранжування для солістів у супроводі ансамблю, серед яких - українські народні та авторські пісні (Баньковський, 2018). Відповідно у другому його випуску було представлено аранжування А. Баньковського для інструментального складу: «Молдавська фантазія», «Гуцульські візерунки» (В. Попадюк), аранжування для солістів у супроводі ансамблю (українські народні та авторські пісні). Крім того, в посібнику вміщена творча довідка про історію створення та діяльність згаданого вище колективу, короткі методичні поради щодо виконання представлених творів, перелік основної рекомендованої літератури, ілюстративний матеріал.

За подібним принципом підготовлено і навчально-методичний посібник із репертуару ансамблю бандуристів при Тернопільському національному педагогічному університеті імені В. Гнатюка (упорядник - заслужений артист України, доцент Д. Губ'як).

Висновки. Представлена нами у статті репрезентація авторських навчально-методичних посібників $€$ неабияк актуальною сьогодні, зокрема матеріали посібників активно використовуються в освітній діяльності закладів загальної середньої та спеціальної музичної освіти, у процесі підготовки майбутніх учителів музичного мистецтва, під час проведення фахових індивідуальних та лекційних занять, семінарів та вебінарів, педагогічної практики, підготовки наукових і творчих проєктів тощо. 
Підготовка і видання фахової репертуарної та методичної літератури не лише сприяє збагаченню репертуарних списків, а й забезпечує викладачів необхідною музикознавчою та методичною інформацією, що служить основою для інтерпретації творів, дослідження та компаративного аналізу становлення стилів та жанрів інструментальної музики українських композиторів.

Сподіваємося, що репрезентовані нами посібники стануть в нагоді для студентів та викладачів мистецьких закладів освіти, виконавців-ансамблістів, організаторів культурно-мистецьких колективів, адже в них представлено впорядкований виконавський репертуар для певного інструментального складу, як-от ансамблів народної музики, ансамблів бандуристів та ін.

Перспективи подальших досліджень плануємо спрямувати на оновлення репертуарного матеріалу, підготовку необхідного музикознавчого та методичного забезпечення з метою формування творчої особистості майбутнього виконавця та педагога, популяризатора української музичної спадщини.

\section{СПИСОК ВИКОРИСТАНОЇ ЛІТЕРАТУРИ}

Козаренко, О. (2000). Феномен української національної музичної мови. Львів: Українознавча бібліотека НТШ. № 15. 286 с.

Михайлов, М. К. (1990). Этюды о стиле в музыке: статьи и фрагменты. Ленинград: Музыка. 288 с.

Українська фортепіанна музика. Педагогічний репертуар для дітей та юнацтва. Частина III. (2010) / упоряд. Т. Завадська, О. Козачук. Київ: Музична Україна. 184 с

Корній, Л. П., Сюта, Б. О. (2014). Українська музична культура. Погляд крізь віки. Київ: Музична Україна. 592 с.

Муха, А. (2004). Композитори України та української діаспори. Київ. 352 с.

Фортепіанні твори українських композиторів: навчальний посібник. (2019) / упоряд.: І. Гринчук, О. Горбач. Тернопіль: ФОП Осадца Ю. В. Вип. 7.96 с.

Кашкадамова, Н. Б. (2017). Фортеп'янно-виконавське мистецтво України: історичні нариси. Львів: КІНПАТРІ ЛТД. 616 с.

Масол, Л. (2006). Загальна мистецька освіта: теорія і практика: монографія. Київ: Промінь. 432 с.

Гринчук, I., Бурська, О. (2008). Проблеми музичного мислення: теорія і методика розвитку. Діалектика музичного логосу і ейдосу: навчально-методичний посібник. Тернопіль: Підручники і посібники. 224 с.

Гринчук, І. П. (2013). Про що і як розповідає музика: посібник-зошит. Тернопіль: Астон. 60 с.

Фортепіанні твори М. Вериківського: навчально-методичний посібник. (2016) / упоряд.: І. Гринчук, О. Горбач. Тернопіль: Астон. 106 с.

Клин, В. (1980). Українська радянська фортепіанна музика. Київ: Наукова думка. 314 с.

Виконавський та навчальний репертуар у класі інструментального ансамблю (з репертуару ансамблю народної музики «Музи́ки»): навчально-методичний посібник. (2018) / упоряд. А. Баньковський. Тернопіль: ФОП Осадца Ю. В. Вип. 1. 100 с.: іл.

\section{REFERENCES}

Kozarenko, O. (2000). Fenomen ukrayins'koyi natsional'noyi muzychnoyi movy [The phenomenon of the Ukrainian national musical language]. L'viv: Ukrayinoznavcha biblioteka NTSH. № 15. 286 p. [in Ukrainian].

Mikhaylov, M. K. (1990). Etyudy o stile v muzyke: stat'i i fragmenty [Etudes about style in music: Articles and fragments]. Leningrad: Muzyka. 288 p. [in Russian].

Ukrainska fortepianna muzyka. Pedahohichnyi repertuar dlia ditei ta yunatstva Chastyna III [Ukrainian piano music. Pedagogical repertoire for children and youth. Part III]. (2010) / uporiadnyky T. Zavadska, O. Kozachuk. Kyiv: Muzychna Ukraina, 184 p. [in Ukrainian].

Kornii, L. P., Siuta, B. O. (2014). Ukrainska muzychna kultura. Pohliad kriz viky [Ukrainian music culture. A look through the ages]. Kyiv: Muzychna Ukraina. 592 p. [in Ukrainian].

Mukha, A. (2004). Kompozytory Ukrainy ta ukrainskoi diaspory [Composers of Ukraine and the Ukrainian Diaspora]. Kyiv. 352 p. [in Ukrainian].

Fortepianni tvory ukrainskykh kompozytoriv: navchalnyi posibnyk [Piano works of Ukrainian composer]. (2019) / uporiad.: I. Hrynchuk, O. Horbach. Ternopil: FOP Osadtcf Ju.V. Vyp. 7. 120 p. [in Ukrainian].

Kashkadamova, N. B. (2017). Fortepianno-vykonavske mystetstvo Ukrainy. Istorychni narysy [Fortepian-performing arts of Ukraine. Historical Essays]. Lviv: KINPATRI LTD, 616 p. [in Ukrainian].

Masol, L. (2006). Zahal'na mystets'ka osvita: teoriya i praktyka [General art education: theory and practice]: monohrafiya. Kyiv: Promin'. 432 p. [in Ukrainian].

Hrynchuk, I., Burska, O. (2008). Problemy muzychnoho myslennia: teoriia i metodyka rozvytku. Dialektyka muzychnoho lohosu i eidosu [Problems of Musical Thinking: Theory and Methods of Development. Dialectics of music logos and eidos]: navchalno-metodychnyi posibnyk. Ternopil: Pidruchnyky i posibnyky. 224 p. [in Ukrainian].

Hrynchuk, I. (2013). Pro shcho i yak rozpovidaie muzyka: posibnyk-zoshyt [What Music Tells You About: a workbook notebook]. Ternopil: Aston. 56 p. [in Ukrainian].

Fortepianni tvory M. Verykivs'koho [Piano works of M. Verykivsky]: navchal'no-metodychnyy posibnyk. (2016) / uporyad.: I. Hrynchuk, O. Horbach. Ternopil': Aston. 106 p. [in Ukrainian].

Klyn, V. (1980). Ukrainska radianska fortepianna muzyka [Ukrainian Soviet piano music]. Kyiv. 314 p. [in Ukrainian].

Vykonavs'kyy ta navchal'nyy repertuar u klasi instrumental'noho ansamblyu (iz repertuaru ansamblyu narodnoyi muzyky «Muzýky») [Performing and educational repertoire in the class of instrumental ensemble (from the repertoire of the folk music ensemble «Music»)]: navchal'no-metodychnyy posibnyk. (2018) / uporyad.: A. Ban'kovs'kyy. Ternopil': FOP Osadtsa YU. V., Vyp. 1. 100 p.: il. [in Ukrainian]. 